\title{
The World at a Crossroads and a System of International Relations for the Future
}

Rivalry and Confrontation or Cooperation and Security

Sergei V. Lavrov

$\mathrm{N}$ ext year we will celebrate two great and interconnected anniversaries-the 75th Anniversary of the Victory in establishment of the UN. Reflecting on the spiritual and moral significance of these landmark events, one needs to bear in mind the enormous political meaning of the victory that ended one of the most brutal wars in the history of mankind.

The defeat of fascism in 1945 fundamentally affected the further course of world history and created conditions for establishing a postwar world order. The UN Charter became its pillar and a key source of international law. The UN-centric system still preserves its sustainability and has a great degree of resilience. It actually serves as a safety net that ensures peaceful development of mankind amid naturally divergent interests and rivalries among leading powers. The WWII experience of ideology-free cooperation of states with different socioeconomic and political systems is still highly relevant.

Sergei V. Lavrov is Minister of Foreign Affairs of the Russian Federation.

DOI: $10.31278 / 1810-6374-2019-17-4-8-18$ 
It is regrettable that this obvious truth is being deliberately silenced or ignored by certain influential forces in the West. Moreover, attempts have intensified to privatize the victory, expunge from memory the Soviet Union's role in the defeat of Nazism, condemn to oblivion the Red Army's feat of sacrifice and liberation, forget the many millions of Soviet citizens who perished during the war, and wipe out from history the consequences of the ruinous policy of appeasement. A look from this perspective reveals the true essence of the concept of expounding the equality of totalitarian regimes. Its purpose is not just to belittle the Soviet Union's contribution to the victory, but also to retrospectively strip our country of its historic role as an architect and guarantor of the postwar world order, and label it a "revisionist power" that is posing a threat to the well-being of the so-called free world.

Interpreting the past in such a manner also means that for some of our partners a major achievement of the postwar system of international relations must be seen in the establishment of a transatlantic link and U.S. permanent military presence in Europe. This is definitely not the scenario the Allies had in mind while creating the United Nations.

The disintegration of the Soviet Union, the fall of the Berlin Wall that had symbolically separated the two "camps," and the disappearance of the irreconcilable ideological standoff that had laid the framework for world politics in virtually all spheres and regions-all those tectonic shifts failed to bring the triumph of a unifying agenda. Instead, all we could hear were triumphant declarations about the "end of history" and the existence of only one global decision-making center.

Today it is obvious that the efforts to establish a unipolar model have failed. The transformation of the world order has become irreversible. New major players wielding a sustainable economic power seek to increase their influence on regional and global developments; they are fully entitled to claim a greater role in the decision-making process. There is a growing demand for more just and inclusive system. The overwhelming majority of the members of the international community 
reject the relapses of arrogant neocolonial policies empowering certain countries to impose their will on others.

All these new developments are greatly disturbing to those who for centuries have become accustomed to setting patterns of global development and enjoying exclusive advantages. While the majority of states aspire to a more fair system of international relations and genuine rather than declarative respect for the UN Charter principles, these demands come up against the policies designed to preserve an order that allows a narrow group of countries and transnational corporations to reap the fruits of globalization. The West's response to the ongoing developments reveals true intentions of its proponents. Their rhetoric on liberalism, democracy and human rights goes hand in hand with the policies of inequality, injustice, selfishness and a belief in their own exceptionalism.

Liberalism, which the West claims to defend, focuses on the individual and personal rights and freedoms. This raises the question: How does it correlate with the policy of sanctions, economic strangulation and overt military threats against independent countries such as Cuba, Iran, Venezuela, North Korea or Syria? Sanctions directly impair the well-being of ordinary people and violate their social and economic rights. How does the imperative of protecting human rights agree with the bombing of sovereign nations, the deliberate policy of destroying their statehood, the loss of hundreds of thousands of lives and immeasurable suffering of millions of Iraqis, Libyans, Syrians and representatives of other peoples? The reckless Arab Spring gamble has destroyed the unique ethnic and religious mosaic in the Middle East and North Africa.

In Europe, the proponents of liberal concepts get along quite well with massive violations of the rights of Russian-speaking citizens in a number of EU and EU-neighboring countries. These countries violate multilateral international conventions by adopting laws that infringe on language and education rights of ethnic minorities.

What is "liberal" about visa denials and other sanctions imposed by the West on the residents of Russia's Crimea? They are punished for their democratic vote in favor of reunification with their historical 
homeland. Does this not contradict the basic right of the people to free self-determination, let alone the right of people to freedom of movement enshrined in international conventions?

Genuine liberalism, in its sound, undistorted sense, has always been an important component of political philosophy both in Russia and worldwide. However, the multiplicity of development models does not allow us to say that the Western "basket" of liberal values has no alternative. And, of course, these values cannot be established by bayonets, by ignoring the history of states, their cultural and political identities. Grief and destruction caused by "liberal" aerial bombings graphically show what this can lead to.

The West's unwillingness to accept today's realities, when after centuries of economic, political and military domination it is losing the prerogative of being the only power to shape the global agenda, has given rise to the concept of a "rules-based order." These "rules" are being invented and selectively combined depending on the fleeting needs of the people behind it, and the West is persistently introducing this language into everyday usage. The concept is by no means abstract and is actively being implemented. Its purpose is to replace the universally agreed international legal instruments and mechanisms with narrow formats, where alternative, nonconsensual methods of resolving various international problems are devised in circumvention of a legitimate multilateral framework. In other words, this is being done on the expectation of usurping the decision-making role in key matters.

The intentions of those who initiated this "rules-based order" concept affect the exceptional powers of the UN Security Council. A recent example: when the United States and its allies failed to convince the Security Council to approve politicized decisions that accused, without any proof, the Syrian government of using prohibited toxic substances, they started to promote the "rules" they needed through the Organization for the Prohibition of Chemical Weapons (OPCW). By manipulating the existing procedures in flagrant violation of the Chemical Weapons Convention, they managed (with the votes of a minority of parties to this Convention) 
to license the OPCW Technical Secretariat to identify those responsible for the use of chemical weapons, which was a direct intrusion in the prerogatives of the UN Security Council. One can also observe similar attempts to "privatize" the secretariats of international organizations in a bid to advance interests outside the framework of universal intergovernmental mechanisms in such areas as biological non-proliferation, peacekeeping, prevention of doping in sports, and others.

The initiatives to regulate journalism aimed to suppress media freedom in an arbitrary way, and the interventionist ideology of "responsibility to protect," which justifies violent "humanitarian interventions" without UN Security Council approval under the pretext of an imminent threat to the security of civilians, are parts of the same policy.

Worthy of separate attention is the moot concept of "countering violent extremism," which lays the blame for the dissemination of radical ideologies and expansion of the social base of terrorism on political regimes that the West has proclaimed undemocratic, illiberal or authoritarian. This concept provides for direct outreach to civil society over the head of legitimate governments. Obviously, its true goal is to withdraw counterterrorism efforts from under the UN umbrella and to obtain a tool for interference in other states' internal affairs.

The introduction of such new concepts is a dangerous phenomenon of revisionism, which rejects the principles of international law embodied in the UN Charter and paves the way back to the times of confrontation and antagonism. It is for a reason that the West is openly discussing a new divide between "the rules-based liberal order" and "authoritarian powers."

Revisionism clearly manifests itself in the area of strategic stability. The torpedoing by the U.S. of the ABM Treaty and the INF Treaty (a decision supported unanimously by NATO members) has generated the risk of dismantling the entire nuclear arms control architecture. The prospects of the Treaty on Measures for the Further Reduction and Limitation of Strategic Offensive Arms (the 
New START) are vague-the U.S. has not given a clear answer to the Russian proposal to extend the New START beyond its expiry date in February 2021.

There are alarming signs of a media campaign unfolding in the United States aimed at laying the groundwork for abandoning the Comprehensive Nuclear Test Ban Treaty (which has not been ratified by the United States). This calls into question the future of this treaty, which is vital for international peace and security. Washington has embarked upon the implementation of its plans to deploy weapons in outer space, rejecting proposals to introduce a universal moratorium on such activities.

Another example of revisionist "rules" is the United States' withdrawal from the Joint Comprehensive Plan of Action on Iran's nuclear program, a multilateral agreement approved by the UN Security Council, which is of paramount importance for nuclear nonproliferation.

Yet another example is Washington's open refusal to implement unanimous UN Security Council resolutions on the settlement of the Israeli-Palestinian conflict.

In the economic field, the "new rules" consist of protectionist barriers, sanctions, abuse of the status of the U.S. dollar as the main means of payment, the use of non-market methods for ensuring competitive advantages, and extraterritorial use of U.S. laws, even against the United States' closest allies.

Simultaneously, the U.S. is persistently trying to mobilize all its foreign partners to contain Russia and China. It does not conceal the desire to sow discord between Moscow and Beijing and undermine multilateral alliances and regional integration projects in Eurasia and Asia-Pacific that are being implemented without its oversight. Pressure is exerted on those countries that do not play by the rules imposed on them and dare make the "wrong choice" of cooperating with the U.S.s "adversaries."

So, what do we have as a result? In politics, erosion of the international legal framework, growth of instability and unsustainability, chaotic fragmentation of the global landscape, 
and deepening mistrust between those involved in international life. In the area of security, blurring of the dividing line between military and non-military means of achieving foreign policy goals, militarization of international relations, increased reliance on nuclear weapons in U.S. security doctrines, lowering of the threshold for the use of such armaments, the emergence of new hotbeds of armed conflicts, the persistence of the global terrorist threat, and militarization of the cyberspace. In the world economy, increased volatility; tougher competition for markets, energy resources and their supply routes; trade wars; and the undermining of the multilateral trade system. One should also add the surge of migration and the deepening of ethnic and religious strife. Do we need such a "rules-based" world order?

Against this background, attempts by Western liberal ideologues to portray Russia as a "revisionist force" are simply absurd. Russia was among the first to draw attention to the transformation of the global political and economic systems that cannot remain static due to the objective march of history. It would be appropriate to mention here that the concept of multipolarity in international relations that accurately reflects the emerging economic and geopolitical realities was formulated two decades ago by outstanding Russian statesman Yevgeny Primakov. His intellectual legacy remains relevant now.

As is evident from the experience of recent years, using unilateral tools to address global problems is doomed to failure. The West-promoted "order" does not meet the needs of humankind's harmonious development. This "order" is non-inclusive; it aims to revise the key international legal mechanisms, rejects the principle of collective action in relations between states, and by definition it cannot generate solutions to global problems that would be viable and stable in the long term rather than seek a propaganda effect within an electoral cycle in this or that country.

What is being proposed by Russia? First of all, it is necessary to keep abreast of the times and recognize the obvious: the emergence of a polycentric world architecture is an irreversible process, no matter 
how hard anyone tries to artificially hold it back (let alone reverse it). Most countries do not want to be held hostage to someone else's geopolitical calculations and are determined to conduct nationally oriented domestic and foreign policies. It is our common interest to ensure that multipolarity be not based on a stark balance of power the way it was at the earlier stages of human history (for example, in the 19th and the first half of the 20th centuries), but be just, democratic and unifying in nature, take into account the approaches and concerns of all those taking part in the international relations without exception, and ensure a stable and secure future.

There are many speculations in the West that a polycentric world order will inevitably lead to more chaos and confrontation because the "centers of power" will fail to come to terms among themselves and take responsible decisions. But, firstly, why not try? What if it works? All that is necessary is to start talks and agree beforehand that the parties should seek a balance of interests. Attempts to invent one's own "rules" and impose them on all others as the absolute truth should be stopped. From now on, all parties should strictly comply with the principles enshrined in the UN Charter, starting with respect for the sovereign equality of states regardless of their size, system of government or development model. Paradoxically, countries that portray themselves as paragons of democracy actually care about it only as they demand that other countries "put their home in order" using the West-inspired pattern. But as soon as the need arises for democracy in intergovernmental relations, they immediately evade honest talk or start interpreting international legal norms at their own discretion.

No doubt, life does not stand still. While taking good care of the post-WWII system of international relations that relies on the United Nations, it is also necessary to cautiously, though gradually, adjust it to the realities of the current geopolitical landscape. This is completely relevant for the UN Security Council, where, judging by today's standards, the West is unfairly overrepresented. We are confident that reforming the Security Council should take into account the interests of Asian, African, and Latin American 
nations, while any such design should rest upon the principle of the broadest consensus among the UN member states. The same approach should apply to improving the world trade system, with special attention paid to harmonizing integration projects in various regions.

We should tap the full potential of the G20, an ambitious, allencompassing global governance body that represents the interests of all key players and takes decisions by common consent. Other associations now play a growing role as well; they project the spirit of a genuinely democratic multipolarity based on voluntary participation, consensus, values of equality and sound pragmatism, and refrain from confrontation and bloc approaches. These include BRICS and the SCO, of which Russia is an active member and which it will chair in 2020.

It is evident that without collective effort and without unbiased partnership under the central coordinating role of the UN it is impossible to curb confrontational tendencies, build up trust and cope with common threats and challenges. It is time we come to consensus on a uniform interpretation of the principles and norms of international law rather than follow the old saying "Might goes before right." It is more difficult to reach accord than to put forward demands, but patiently negotiated trade-offs will be a much more reliable vehicle for predictable handling of international affairs. Such an approach is badly needed for launching substantive talks on the terms and conditions of a reliable and just system of equal and indivisible security in the EuroAtlantic region and Eurasia. This objective has been declared multiple times at the top level in OSCE documents. It is necessary to move from words to real action now. The Commonwealth of Independent States (CIS) and the Collective Security Treaty Organization (CSTO) have repeatedly expressed their readiness to contribute to such efforts.

It is important to increase cooperation towards peaceful resolution of numerous conflicts, be it in the Middle East, Africa, Asia, Latin America or the post-Soviet space. The main point is to abide by earlier arrangements rather than invent pretexts for refusing to fulfil obligations. 
It is especially important today to counter religious and ethnic intolerance. We urge all nations to work together to prepare for the World Conference on Interfaith and Interethnic Dialogue that will be held in Russia in May 2022 under the auspices of the InterParliamentary Union and the UN. The OSCE that has formulated a principled position condemning anti-Semitism should act with equal resolve against Christianophobia and Islamophobia.

Our unconditional priority is to continue promoting the formation of the Greater Eurasian Partnership, a broad integration framework stretching from the Atlantic to the Pacific and involving the member states of the Eurasian Economic Union (EAEU), the Shanghai Cooperation Organization (SCO), the Association of Southeast Asian Nations (ASEAN) and all other countries of the Eurasian continent, including the EU countries. It would be unwise to contain the unifying processes or, worse still, to put up fences. It would be a mistake to reject the obvious strategic advantages of our common Eurasian region in the modern increasingly competitive world.

Consistent efforts towards reaching this constructive goal will allow us not only to ensure the dynamic development of national economies and remove obstacles to the movement of goods, capital, labor, and services, but also to create a solid foundation of security and stability across the vast region from Lisbon to Jakarta.

Will the multipolar world continue to take shape through cooperation and harmonization of interests or through confrontation and rivalry? This depends on all of us. Russia will continue to promote a positive and unifying agenda aimed at removing the old dividing lines and preventing the appearance of new ones. Russia has advanced initiatives to prevent an arms race in outer space, establish efficient mechanisms for combating terrorism, including chemical and biological terrorism, and to agree upon practical measures to prevent the use of cyberspace for undermining national security or for other criminal purposes.

Our proposals to launch a serious discussion on all aspects of strategic stability in the modern era are still valid. 
Ideas have been voiced recently to modify the agenda and update the terms. The proposed subjects for discussion vary from "strategic rivalry" to "multilateral deterrence." Terminology is negotiable, but it is not terms but the essence that really matters. It is now much more important to start a strategic dialogue on concrete threats and risks and to seek consensus on a commonly acceptable agenda. As another outstanding Russian statesman, Andrei Gromyko (his 110th birth anniversary we mark this year), said wisely, "It's better to have ten years of negotiations than one day of war." 